\title{
EVALUATION OF THE APPLICATION OF AN INCLUSIVE EDUCATION POLICY ON SCREENING, IDENTIFICATION, ASSESSMENT AND SUPPORT OF THE LEARNERS AT SCHOOLS IN SOUTH AFRICA
}

(iD) Mantheme Florina
Matolo $^{1}$
(D) Awelani M.
Rambuda $^{2+}$

\author{
'Department of Social Sciences, Bahale Secondary School, Free State, South \\ Africa. \\ Email:man.flomatolo@gmail.com Tel:+27749457774. \\ ${ }^{2}$ Faculty of Humanities, Department of Educational and Professional \\ Studies, Central University of Technology, Free State, South Africa. \\ Email:arambuda@,cut.ac.za Tel: +27824918014.
}

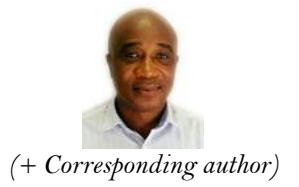

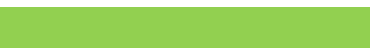

Article History

Received: 27 July 2021 Revised: 6 December 2021 Accepted: 23 December 2021 Published: 4 January 2022

\section{Keywords}

Assessment of barriers to learning Identification of barriers to learning

Inclusive education Screening of barriers to learning SIAS 2014 policy
Policy application

Support of learners with barriers.

\begin{abstract}
The aim of this research was to evaluate the application of an inclusive education policy on screening, identification, assessment and support of learners (SIAS) policy at South African schools. The research explores how educators screen, identify, and assess barriers to learning as well as support learners with barriers. The variables on the screening, identification, assessment and support of learners were chosen as a focal point of this study mainly because they were all variables contained in the policy which must be mastered by the educators during the policy application. A survey design of quantitative research approach was followed. Document analysis of the SIAS 2014 policy document was done over the target population of educators in primary and secondary schools. A simple random sampling technique was used to select 320 male and female respondents from both primary and secondary schools. The quantitative data were collected using a seven-point semantic differential scale which elicited responses from a total of 250 educators. Descriptive statistics were used to analyze data on the educators' responses about the extent to which they implemented the inclusive education policy. Statistical data revealed that the implementation of the policy was modest. Educators do not effectively use the screen resources such as the learner profile to screen barriers and the Support Needs Assessment 1 is not effectively used to identify and assess the barriers experienced by learners. As a result, support of learners was found to be inadequate. An independent-samples t-test revealed that there was statistically significant difference between the means of primary and secondary schools in the application of SIAS 2014 policy. This research recommends that the teacher training institutions should capacitate aspiring educators about inclusive education policies such as the SIAS 2014 policy rationale, principles, and how the policy is to be effectively implemented at schools.
\end{abstract}

Contribution/Originality: This study is one of very few studies which have investigated the application of an inclusive education policy on screening, identification, assessment and support of learners (SIAS) 2014 policy at South African schools. An effective implementation of this policy will depend largely on educators' training and development.

\section{INTRODUCTION}

South Africa (SA) is one of the countries of the world that uphold human rights of which right to quality education is one of them. The education department in South Africa grounds all its practices in policy and effective implementation. Like in many countries, an inclusive education system that enables access to quality education 
remains a quest in South Africa that unfortunately does not yet seem to be achieved. Primary and secondary schools in South Africa are expected to effectively apply the 2014 Screening, Identification, Assessment and Support (SIAS) policy. Moreover, all educators are equally expected to play a vital role of screening, identifying and assessing barriers to learning in their daily teaching. Subsequently, they must render support to any learner who may be experiencing barriers to learning. On the contrary, there is a disparity between the manner primary and secondary schools apply the policy. This study embarked on evaluating the extent to which the policy was implemented by educators as a whole and how primary and secondary schools applied the SIAS 2014 policy based on the rationale of the policy.

According to Chapter Two Section 3(1) of the SIAS 2014 policy, the first rationale is based on promoting the principles of White Paper 6 by focusing on overcoming barriers in the education system that prevent it from meeting the full range of learning needs (Department of Basic Education, 2014). This implies that even if an educator who is to implement the SIAS policy is not sure of the principles of the White Paper 6, such an educator needs to understand that the major focus of the policy is to overcome the barriers that prevent learning from taking place. In an ideal situation, the barriers implied here are those that educators may identify in learners or in the learners' environments. The second rationale in Chapter Two Section 4(1) of the policy is the commitment of South Africa to the United Nations Convention on the Rights of People with Disabilities about zero rejection of learners based on their disability in all schools. Educators need to have a thorough understanding of what disability entails and what the implications are for accommodating learners with disabilities. Since the policy is based on zero rejection of learners with disability, the implication is that this research needs to evaluate the application of the policy. Section 5 of Chapter Two of the SIAS 2014 policy is also based on the third rationale of addressing barriers to learning and development. This rationale paves way to the support of learners who experience barriers to learning by all stakeholders in the education system. Examples of barriers outlined in Chapter Two Section 5(2) of the policy include socio-economic aspects such as poverty; factors that place learners at risk, such as physical, emotional and sexual abuse; political violence; and attitudes.

\section{LITERATURE REVIEW}

Policy implementation is believed to be an act of following step-by-step policy prescripts legislatively (Bowe \& Ball in Stofile (2008)). This means that in both primary and secondary schools, both female and male educators should uniformly apply any SA education policy such as the SIAS 2014 policy. To ensure that all learners can access quality education that helps achieve the Constitutional aims of SA, it is imperative that educators are conversant with barriers to learning. A barrier to learning means an obstacle or something that prevents a learner from learning or militates learning to be effective. It refers to difficulties that arise within the education system as a whole, the learning site and/or within the learners themselves, which prevent access to learning and development for learners (Department of Basic Education, 2014; Department of Education, 2008; Swart \& Pettipher, 2016).

Examples of barriers to learning include socioeconomic factors such as poverty and impairments that may be physical, cognitive, sensory, and/or developmental. Educators need to have a profound understanding of barriers to learning, not only for them to support learners who may be experiencing those barriers, but also for them to guard against aggravating such barriers with their performance at workplace. The policy requires an understanding of educational inclusivity by compelling primary and secondary educators to bear in mind that their focus in addressing educational needs in their daily practice should no longer be on the nature of a learner but rather on the nature of the barrier that prevents the learner from learning as well as the nature of support that may be suitable to assist the learner (Department of Basic Education, 2014). South African educators at primary and secondary schools are expected to apply the prescripts of the SIAS 2014 policy which are discussed below. 


\subsection{Screening}

Screening means testing for the presence or absence of a barrier to learning. In this research the word 'screen' is one of the SIAS 2014 policy processes denoted by the first 'S' in the acronym. The process involves having an entire class or school administratively checked (screened) to determine who among the learners is at risk of having a disability and who needs additional help (Taylor, Smiley, \& Richards, 2015). Screening also means gaining knowledge of and about a learner. This knowledge is held in high regard by acclaimed international associations such as the National Association for the Education of Young Children (NAEYC) which is acknowledged by Deiner (2013). Knowledge about learners' learning development requires educators to understand patterns of their growth and development so that educators can adapt to and be responsive to individual variations (NAEYC in Deiner (2013)). In the SIAS 2014 policy, the screening of barriers is conducted using a Learner Profile provided along with the policy document by a class educator.

By screening the barriers in a learner, an educator would gain the background information on the learner by filling in a learner profile for each learner to determine whether a learner has been noted as experiencing barriers to learning in their previous grades. Factors that can act as barriers to learning can be classified as either intrinsic barriers or extrinsic barriers ( $\mathrm{Nel}, \mathrm{Nel}, \&$ Hugo, 2012). Educators are to focus the screening process not only on the barriers within the learners but also on their environment according to the theory of Bronfenbrenner (1979) namely the bioecological model. The researchers believe the bioecological model will have been applied appropriately because all factors within and outside a learner will have been explored. Anything that prevents effective learning from taking place is considered a barrier (Nel et al., 2012). This is done by way of systematically asking questions about that person or any entity to select from the responses what might yield a clue to the enquiry established about that person or entity.

\subsection{Identification}

To 'identify' means to recognize a learning barrier that hinders effective learning from taking place. In this research the word 'identify' is one of the SIAS 2014 policy processes denoted by 'I' in the acronym. Educators embark on labelling and extrapolating the nature of barriers that are within a learner or around a learner and which interrupts the smooth learning process. Gargiulo and Metcalf (2013) stipulate that the identification of barriers by an educator involves assessing the available data from different sources that typically profile a learner's strengths and needs. In the case of the SIAS 2014 policy application, educators examine completed Learner Profiles, the School Self Evaluation (SSE) tool, as well as interaction with parents and care-givers to gain knowledge that will assist them to determine the nature of the barriers that obstruct learners from effective learning. The identification at this stage is only limited to those learners for whom the screening stage raises the concern of the educator.

(Carkhuff, 2009) regards anyone who endeavours to identify needs in the lives of others with a purpose of bringing about an intervention as a helper while anyone who experiences the need for intervention is a helpee. Educators identifying barriers in the academic lives of learners can therefore be referred to as helpers while learners experiencing barriers are helpees. The first skill of identifying barriers by helpers is called 'attending'. Being an effective learner observer requires suspending judgement and interpretation of the events and instead focusing on describing the phenomena that the educator sees (Barringer, Pohlman, \& Robinson, 2010). The same idea of educators' objective observation and listening is supported by Tomlinson (2014) who attests that educators should allow learners to figure things out for themselves. Educators are only to provide directions and guidelines for quality, but they should leave some ambiguity, choice, and flexibility so that learners have to make leaps of transfer and apply common sense (Tomlinson, 2014). The identification of barriers in the SIAS 2014 policy is guided by a form known as Special Needs Assessment 1 (SNA 1). After a learner has been identified as being vulnerable, the class educator is responsible for coordinating support processes by first involving the parents and learners who are over twelve years during the decision-making processes of SIAS. Thereafter, Individual Support Plan (ISP) is 
drawn up for learners who are found to be experiencing barriers (Department of Basic Education, 2014). The implications of these directives are that educators should be familiar with these administrative forms for their daily application of the SIAS 2014 policy. They need to understand that assuming the role of a case manager means they need to know exactly how and why they fill in the SNA 1 and the ISP. They also need to ensure that their application processes are in line with the rationale of the policy.

\subsection{Assessment}

This research contains one of the SIAS 2014 policy processes denoted by 'A' in the acronym. In this inclusive education policy, the assessment process is not fundamentally confined to the measurement of curriculum content mastered by learners, but it means the exploration of barriers to learning that are experienced by the learners. The assessment of barriers is done by an educator or school and/or the entire education system to grade the level or intensity of barriers within or around learners. Bouwer (2016) describes the process of assessment as an act of focusing on how learners cope when a new or complex skill is being taught so that necessary adjustments can be made. In support of this viewpoint, Glazzard, Stokoe, Hughes, Netherwood, and Nerve (2015) attest that the needs assessment includes the review of all available evidence such as the information about a learner's personal, social and emotional development. This may also include establishing the nature of the intervention rendered for the learners about the needs they may experience. The policy refers to the assessment of barriers to determine the support needs of learners, not assessment of scholastic achievement or assessment of learners who experience barriers to learning. The results of assessment should be clearly, accurately, and timeously documented and communicated to those affected (Department of Basic Education, 2014). For effective implementation of the SIAS 2014 policy, educators will assess the support needs of learners from time to time so that all learners, namely those who experience barriers to learning as well as those who do not, are able to acquire quality education. Therefore, assessment should provide all learners with opportunities to show what they know or do not know and what they can do or not do. This will enable educators to provide adequate learning support in an inclusive education system. Educators will apply learning support approaches that accommodate diversity of learners.

2.4. Support

In this research the word 'support' is one of the SIAS 2014 policy processes denoted by the second 'S' in the acronym. Support of learners means a solution-focused process about identifying and addressing the individual needs of learners who require an additional teaching strategy or approach (Landsberg \& Matthews, 2016). Support of learners who experience barriers to learning involves different approaches. These are all based on yielding a counter-effect to barriers. Educators need to explore as many approaches and strategies as there are differences in learners. Gargiulo and Metcalf (2013) also emphasise the need for educators to understand that supporting learners who experience barriers to learning starts with an individualised support plan in which educators may select a barrier which they wish to define and target for change by tracking, observing and measuring its frequency before teaching and reinforcing counter-barrier modes can be applied. At the beginning of this study, it was not clear how effective the implementation of the SIAS policy was in schools because seemingly, according to the policy directives, the roles of the class educator and the subject educator did not make a logical role-playing.

\section{THEORETICAL FRAMEWORK}

The history of inclusive education policy dates to the pre-democratic era in South Africa. The medical deficit model or within-child model was commonly applied. This is a model that views a learner as a patient who is deficient in a particular aspect of learning life and becomes treated for such illness until the deficit is remedied. Alternatively, the learner is removed from a local school set-up to a special school set-up that has been established for learners with the same deficit. In this model, learners were identified as having special educational needs and 
were therefore referred to centres which were hoped would find out "what is wrong" with people and "fix" them (Swart \& Pettipher, 2016). This model was highly criticized, not only for its labelling approach, but also for the fact that in apartheid affected South Africa, only the white minority group could benefit from this educational service while the majority of black learners living in rural areas were left unaided. The democratic era in South Africa marked the beginning of a paradigm shift in education policy from both the "special" and "general" education system to an education system that can identify and address learning diversity and needs among all learners.

The SIAS policy is based on the Bronfenbrenner's bioecological theory which was first initiated in 1979 but later developed as recently as 2006 and 2009. The policy adopts the Bronfenbrenner's ecosystem perspective which requires basic education to shift from locating barriers within the learners but to locating them in all the systems which form spheres of the existence of learners, and which act as barriers to learning. These include the family, the educators in school and aspects of community functioning (Hay in Stofile (2008)). Effective application of SIAS 2014 policy will maintain the sovereignty of all the social contexts of learners' existence. The question is, do educators apply the inclusive education policy on screening, identification, assessment and support of learners (SIAS) policy at South African schools? The systems from which barriers and support intervention may be located are presented in Figure 1 in a form of nests that represent their interconnectedness in Bronfenbrenner's bioecological theory.

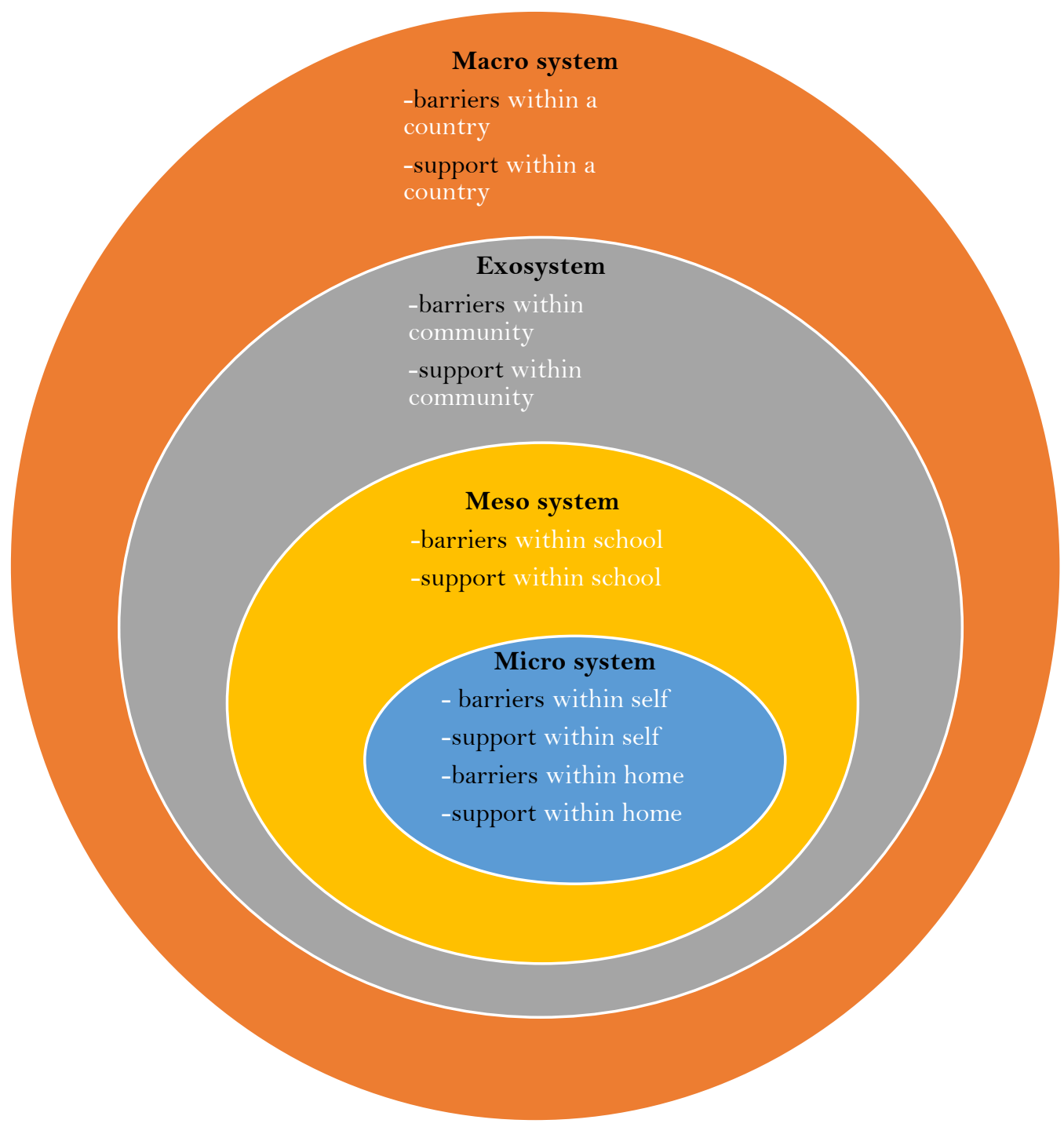

Figure 1. Nested structures summarizing environmental or social contexts of learners (Swart \& Pettipher, 2016). 
Figure 1 shows a relationship that exists within an ecosystem. In each system, there may not only be barriers which influence learning of learners but also support factors that can counteract the barriers. The implication portrayed in Figure 1 for implementers of the SIAS 2014 policy is that educators must explore both barriers and support factors within a learner's operational system thoroughly before they can refer to other systems for assistance. For example, educators in a school need to screen and identify the barriers which affect learning of learners; then assess the level and nature of support structures available within the school; and then render support before a referral for assistance from another system (nest) can be sought. It is only when all the support modes within the school have been exhausted can referral for support be made from another system (which still has its own barriers and support factors). From Figure 1, it can further be noted that the barriers to learning may not be emanating from an individual learner only, but they may be caused by other systems such as home, school or community. A learner is portrayed as one of the areas from which barriers may be located, hence the adamant rationale of the SIAS 2014 policy of shifting the focus from the learner but to the barriers which then influence the learner. The barriers from any of the systems may influence lives of learners and so impact on the learning ability of learners.

\section{METHODOLOGY}

A positivist research paradigm was adopted in this research. The stance of positivism insists that only what researchers can empirically observe is important. In a positivist paradigm observation and reason are used as means of understanding behaviour (Cohen, Manion, \& Morrison, 2018; Fraenkel, Wallen, \& Hyun, 2015; Grbich, 2013; Jansen, 2016; Johnson \& Christensen, 2017; Leedy \& Ormord, 2015; Moyo, Modiba, \& Simwa, 2015). This is descriptive research that aims to compare the application of the SIAS 2014 policy as an inclusive education policy practice between primary and secondary schools.

\subsection{Respondents}

The target population was all primary and secondary school educators because they are the first line of SIAS 2014 policy implementation by being the first to register learners in their classes and establish Learner Profiles for them. As a result, the first step of the SIAS 2014 policy implementation starts with educators in the classroom screening learners using a Learner Profile. The identified sample size was 160 male and 160 female educators who totalled 320 in all. Simple random sampling technique, using a Table of Uniform Random Numbers was employed to administer the 320 questionnaires of which $250(78.12 \%)$ were returned while $7(2.19 \%)$ were spoiled. 63 $(19.68 \%)$ questionnaires were never returned and reasons forwarded by respondents ranged from misplacement to lack of time to fill them in.

\subsection{Data Collection}

In this research a structured questionnaire was designed for data collection from educators. This type of questionnaire was chosen because it was directly to the point and more focused (Cohen et al., 2018). Variables of closed-ended items were measured on a seven-point semantic differential scale, where the respondents chose 1 to denote how strongly they disagreed with a questionnaire statement or 7 to denote how strongly they agreed. The questionnaire reliability revealed a high internal consistency with a Cronbach's alpha coefficient of .91.

\subsection{Data Analysis}

In this research, the researchers analysed the data collected to summarise them in a dependable and accurate manner, leading to the presentation of study findings in a manner that has an air of undeniability. Analysis of the quantitative data collected about the nature of the SIAS policy and how the educators implemented the policy was conducted using the SPSS Version 25 statistical program. 


\section{RESULTS}

The findings of this research about this policy application are presented in the form of tables below. In each table, the first column represents the code and statements stated in Section B of the questionnaire that was on a seven-point scale. The remaining four columns represent the constructs, mean, median and standard deviation. An analysis of the data scores is done after each table.

Table 1. Implementation of SIAS 2014 policy, educators.

$\mathrm{N}=250$

\begin{tabular}{|c|c|c|c|c|c|c|}
\hline \multicolumn{2}{|c|}{ Questionnaire items } & Constructs & Mean & Median & Standard & Cronbach's \\
\hline B1 & $\begin{array}{l}\text { My characteristics influence barriers in } \\
\text { learners. }\end{array}$ & \multirow{3}{*}{$\begin{array}{c}\text { Educator } \\
\text { characteristics }\end{array}$} & \multirow[b]{3}{*}{4.63} & \multirow[b]{3}{*}{4.67} & \multirow[b]{3}{*}{1.59} & \multirow[b]{3}{*}{0.55} \\
\hline B4 & $\begin{array}{l}\text { I have empathy for learners with learning } \\
\text { disabilities. }\end{array}$ & & & & & \\
\hline B5 & $\begin{array}{l}\text { I love teaching learners with learning } \\
\text { difficulties. }\end{array}$ & & & & & \\
\hline D12 & $\begin{array}{l}\text { My school outsources professional experts } \\
\text { and practitioners to develop me on how to } \\
\text { screen barriers in the learners I teach. }\end{array}$ & \multirow[b]{3}{*}{$\begin{array}{l}\text { External } \\
\text { training }\end{array}$} & \multirow[b]{3}{*}{3.51} & \multirow[b]{3}{*}{2.67} & \multirow[b]{3}{*}{1.89} & \multirow[b]{3}{*}{0.79} \\
\hline D22 & $\begin{array}{l}\text { I can complete the Area of Need because I } \\
\text { was taught how to do it in my teacher } \\
\text { training programme. }\end{array}$ & & & & & \\
\hline D24 & $\begin{array}{l}\text { The District Based Support Team (DBST) } \\
\text { has developed me to complete the Area of } \\
\text { Need. }\end{array}$ & & & & & \\
\hline D23 & $\begin{array}{l}\text { The School Based Support Team (SBST) } \\
\text { has developed me to complete the Area of } \\
\text { Need. }\end{array}$ & \multirow[b]{2}{*}{ Internal training } & \multirow[b]{2}{*}{3.64} & \multirow[b]{2}{*}{4.00} & \multirow[b]{2}{*}{1.89} & \multirow[b]{2}{*}{0.84} \\
\hline D25 & $\begin{array}{l}\text { I can complete the Area of Need because I } \\
\text { have been developed through Integrated } \\
\text { Quality Management System (IQMS) } \\
\text { programs. }\end{array}$ & & & & & \\
\hline B2 & $\begin{array}{l}\text { I am able to implement the SIAS } 2014 \\
\text { policy effectively. }\end{array}$ & \multirow[b]{3}{*}{$\begin{array}{l}\text { Educators' perceived } \\
\text { ability to implement } \\
\text { the policy }\end{array}$} & \multirow[b]{3}{*}{4.27} & \multirow[b]{3}{*}{4.67} & \multirow[b]{3}{*}{1.72} & \multirow[b]{3}{*}{0.72} \\
\hline B3 & $\begin{array}{l}\text { I can screen, identify, assess and support } \\
\text { learners who experience barriers to } \\
\text { learning. }\end{array}$ & & & & & \\
\hline B6 & $\begin{array}{l}\text { I am able to keep Curriculum and } \\
\text { Assessment Policy Statement (CAPS) pace } \\
\text { in an inclusive teaching and learning } \\
\text { environment. }\end{array}$ & & & & & \\
\hline $\mathrm{C} 1$ & $\begin{array}{l}\text { I understand the policy rationale about } \\
\text { learning barriers. }\end{array}$ & \multirow{3}{*}{ Policy knowledge } & \multirow{3}{*}{4.43} & \multirow{3}{*}{5.00} & \multirow{3}{*}{1.60} & \multirow{3}{*}{0.91} \\
\hline $\mathrm{C}_{2}$ & $\begin{array}{l}\text { I understand that the policy is a shift from a } \\
\text { clinical model to the one that emphasizes } \\
\text { human rights. }\end{array}$ & & & & & \\
\hline C3 & $\begin{array}{l}\text { I understand the differences about the } \\
\text { learning barriers that are systemic, societal, } \\
\text { pedagogical and/or intrinsic. }\end{array}$ & & & & & \\
\hline
\end{tabular}

The analysis of data in Table 1 shows that there is a low internal consistency of reliability $(\alpha=0.55)$ on items B1, B4 and B5 about the impact of educator characteristics. Data in this table reveal that the educators' having empathy for learners moderately influences the policy implementation $(M=4.63 ; M D=4.67 ; S D=1.59)$. Data are negatively skewed as the mean is below the median which suggests that the respondents agree on these items since the standard deviation is not far from the mean. The impact of external training of educators tested in questionnaire items D12, D22 and D24 reached an acceptable internal consistency of reliability $(\alpha=.79)$. However, data reveal that external training and the development of educators do not contribute to the effective implementation of the policy $(M=3.51 ; M D=2.67 ; S D=1.89)$. The mean is above the median, showing a positively skewed data and the 
standard deviation is far from the mean, revealing that there is no agreement among the respondents about the external training and development of educators. As regard internal training of educators, items D23 and D25 reached a good internal consistency $(\alpha=.84)$. Data reveal that no internal training or development for educators are done by the School Based Support Team (SBST) and schools' development teams (through Integrated Quality Management System) $(M=3.64 ; M D=4.00 ; S D=1.89)$. Data are negatively skewed because the mean is below the median. Respondents do not agree on these items; hence the standard deviation is far from the mean. The Cronbach's alpha further reveals an acceptable internal consistency of reliability $(\alpha=.72)$ on items B2, B3 and B6 educators' perceived ability to implement the policy. Data shows that educators are moderately able to keep Curriculum and Assessment Policy System (CAPS) pace in an inclusive environment $(M=4.27 ; M D=4.67 ; S D=$ 1.72). Data are also negatively skewed because the mean is below the median and there is no agreement among respondents about these items since the standard deviation is far from the mean. Data show that the questionnaire items C1, C2 and C3 reached an excellent internal consistency. Educators moderately know and understand the policy $(M=4.43 ; M D=5.00 ; S D=1.60)$. Data are negatively skewed since the mean is below the median and the respondents agree on these items because the standard deviation is not far from the mean.

Table-2. Implementation of SIAS 2014 policy, school governance.

\begin{tabular}{|c|c|c|c|c|c|c|}
\hline \multicolumn{2}{|c|}{ Questionnaire items } & \multirow[t]{2}{*}{ Construct } & Mean & Median & Standard & Cronbach's \\
\hline D3 & $\begin{array}{l}\text { My principal ensures functionality of } \\
\text { the School Based Support Team } \\
\text { (SBST). }\end{array}$ & & \multirow[b]{2}{*}{5.02} & \multirow[b]{2}{*}{5.50} & \multirow[b]{2}{*}{1.64} & \multirow[b]{2}{*}{0.70} \\
\hline D10 & $\begin{array}{l}\text { My principal ensures functionality of } \\
\text { the school governing Body (SGB) sub- } \\
\text { committee for support of learners with } \\
\text { barriers. }\end{array}$ & $\begin{array}{c}\text { school } \\
\text { governance }\end{array}$ & & & & \\
\hline
\end{tabular}

Table 3. Implementation of SIAS 2014 policy, Learners.

\begin{tabular}{|c|c|c|c|c|c|c|}
\hline \multicolumn{2}{|c|}{ Questionnaire items } & Constructs & Mean & Median & Standard & Cronbach's \\
\hline D1 & $\begin{array}{l}\text { I can establish vulnerability of } \\
\text { learners in the subject(s) that I teach. }\end{array}$ & \multirow{3}{*}{$\begin{array}{l}\text { Learner } \\
\text { vulnerability }\end{array}$} & \multirow{3}{*}{4.29} & \multirow{3}{*}{4.33} & \multirow{3}{*}{1.71} & \multirow{3}{*}{0.73} \\
\hline F11 & $\begin{array}{l}\text { My Head of Department } \\
\text { (HOD)/supervisor develops me on } \\
\text { how I should best support vulnerable } \\
\text { learners in my class. }\end{array}$ & & & & & \\
\hline F12 & $\begin{array}{l}\text { We discuss support to vulnerable } \\
\text { learners as an item in staff meetings. }\end{array}$ & & & & & \\
\hline $\mathrm{D} 2$ & $\begin{array}{l}\text { My supervisor controls and monitors } \\
\text { all Learner Profiles of learners I have } \\
\text { screened. }\end{array}$ & \multirow{4}{*}{$\begin{array}{l}\text { Control and } \\
\text { monitoring of } \\
\text { learner } \\
\text { profiles }\end{array}$} & \multirow{4}{*}{4.22} & \multirow{4}{*}{4.55} & \multirow{4}{*}{1.88} & \multirow{4}{*}{0.63} \\
\hline D6 & $\begin{array}{l}\text { The information on each Learner } \\
\text { Profile is sufficiently detailed for me } \\
\text { to understand all learning barriers } \\
\text { that exist in each learner's } \\
\text { environment. }\end{array}$ & & & & & \\
\hline D8 & $\begin{array}{l}\text { There should be a photograph of a } \\
\text { learner on the Learner's Profile } \\
\text { during the screening process. }\end{array}$ & & & & & \\
\hline E5 & $\begin{array}{l}\text { I ensure that a learner has a Learner } \\
\text { Profile before I fill in the Support } \\
\text { Needs Assessment (SNA 1) for such } \\
\text { a learner. }\end{array}$ & & & & & \\
\hline
\end{tabular}


Statistical data in Table 2 reveal that the questionnaire items D3 and D10 which are related to the role played by school governance in the SIAS policy implementation show an acceptable internal consistency $(\alpha=0.70)$ in Cronbach's alpha. Data reveal that, the SBST and school governing body (SGB) sub-committees are functional in schools $(M=5.02 ; M D=5.50 ; S D=1.64)$. Data are negatively skewed because the mean is below the median. The standard deviation is not far from the mean, and this shows that the respondents agree on these items. The following table provides data which measured learners as a variable in the implementation of the SIAS2014 policy.

Analysis of data in Table 3 shows that there is an acceptable internal consistency of reliability in the questionnaire items D1, F11 and F12 $(\alpha=0.73)$. Data in the table show learner vulnerability as moderately addressed in schools $(M=4.29 ; M D=4.33 ; S D=1.64)$. Data are negatively skewed as the mean is below the median. There is agreement among respondents because the standard deviation is not far from the mean. Data about questionnaire items $\mathrm{D} 2, \mathrm{D} 6, \mathrm{D} 8$, and E5 show that there is a low internal consistency of reliability $(\alpha=63)$. Data also reveal that control and monitoring of learner profiles are moderately done at schools $(M=4.22 ; M D=$ 4.55; $S D=1.88$ ). Data are negatively skewed because the mean is lower than the median. The standard deviation is far from the mean which means that there is no agreement among respondents about the items.

Table-4. Implementation of SIAS 2014 policy, screening process.

$(\mathrm{N}=250)$

\begin{tabular}{|c|c|c|c|c|c|c|}
\hline \multicolumn{2}{|c|}{ Questionnaire Items } & Constructs & Mean & Median & Standard & Cronbach's \\
\hline $\mathrm{D} 4$ & $\begin{array}{l}\text { I use the School Self Evaluation (SSE) to screen } \\
\text { barriers that influence learning of learners. }\end{array}$ & \multirow[b]{3}{*}{$\begin{array}{l}\text { Screening } \\
\text { resources }\end{array}$} & \multirow{3}{*}{4.41} & \multirow{3}{*}{4.50} & \multirow{3}{*}{1.69} & \multirow{3}{*}{0.75} \\
\hline D5 & $\begin{array}{l}\text { I use the Subject Improvement Plan (SIP) to screen } \\
\text { barriers that influence learning of learners. }\end{array}$ & & & & & \\
\hline D9 & $\begin{array}{l}\text { I screen all barriers in learners I teach regardless of } \\
\text { whether I am their class teacher. }\end{array}$ & & & & & \\
\hline $\mathrm{D} 7$ & $\begin{array}{l}\text { My School Based Support Team consults with my } \\
\text { Head of Department after I have made a referral } \\
\text { about a learner who experiences learning barriers. }\end{array}$ & \multirow{4}{*}{$\begin{array}{l}\text { Learner } \\
\text { referral }\end{array}$} & \multirow{4}{*}{3.74} & \multirow{4}{*}{3.75} & \multirow{4}{*}{1.79} & \multirow{4}{*}{0.73} \\
\hline D14 & $\begin{array}{l}\text { The School Based Support Team provides timeous } \\
\text { support to my referrals of screened learners. }\end{array}$ & & & & & \\
\hline E6 & $\begin{array}{l}\text { I use Form 124 (List of Accommodations and } \\
\text { Exemptions) to identify, assess and track progress } \\
\text { of the needs of learners I have screened. }\end{array}$ & & & & & \\
\hline E7 & $\begin{array}{l}\text { I use Form } 125 \text { (Curriculum Differentiation } \\
\text { Schedule) to identify, assess and track progress of } \\
\text { the needs of learners I have screened. }\end{array}$ & & & & & \\
\hline D15 & $\begin{array}{l}\text { I write one or two different years within the age of } \\
\text { five when a learner receives a service and } \\
\text { intervention on their area of need at the time. }\end{array}$ & \multirow{7}{*}{$\begin{array}{l}\text { Screening } \\
\text { process }\end{array}$} & \multirow{7}{*}{3.58} & \multirow{7}{*}{4.00} & \multirow{7}{*}{1.82} & \multirow{7}{*}{0.91} \\
\hline D16 & $\begin{array}{l}\text { I write anything when I deal with learners above } \\
\text { the age of five. }\end{array}$ & & & & & \\
\hline D17 & $\begin{array}{l}\text { I know where and how I should gather information } \\
\text { about the area of need of the learner I screen. }\end{array}$ & & & & & \\
\hline D18 & $\begin{array}{l}\text { I write the services and/or interventions that a } \\
\text { learner received during their } 6 \text {-10 year-old period } \\
\text { and } 11-15 \text { year old period respectively. }\end{array}$ & & & & & \\
\hline $\bar{D} 19$ & $\begin{array}{l}\text { On the MM/YY, I write the month and year in } \\
\text { which the area of need was first discovered. }\end{array}$ & & & & & \\
\hline D20 & $\begin{array}{l}\text { On the grade, I write the grade in which the learner } \\
\text { was when the barrier was first discovered. }\end{array}$ & & & & & \\
\hline D21 & $\begin{array}{l}\text { I am guided by the SIAS policy directives on how } \\
\text { to identify a learner's area of need. }\end{array}$ & & & & & \\
\hline
\end{tabular}

Data in Table 4 reveal that there is an acceptable internal consistency of reliability in the questionnaire items D4, D5 and D9 $(\alpha=0.75)$. Data reveal that the screening resources such as School Self Evaluation (SSE) and Subject Improvement Plan (SIP) are moderately used to facilitate an effective policy implementation during the 
screening process $(M=4.41 ; M D=4.50 ; S D=1.69)$. Data are negatively skewed because the mean is lower than the median. There is agreement among respondents about the items because the standard deviation is not far from the mean. There is an acceptable internal consistency of reliability in the questionnaire items D7, D14, E6 and E7 $(\alpha=.73)$. Data show that educators do not screen the barriers in the learners for referral purposes $(M=3.74 ; M D=$ 3.75; $S D=1.79$ ). Data are negatively skewed because the mean is below the median. The respondents do not agree on these items because the standard deviation is far from the mean. Lastly, on the screening process, there is an excellent internal consistency of reliability in the questionnaire items D15, D16, D17, D18, D19, D20 and D21 ( $\alpha=$ .91). Data reveal that screening of barriers regarding early intervention services rendered to a learner is not done $(M=3.58 ; M D=4.00 ; S D=1.82)$. Data are negatively skewed because the mean is below the median. There is no agreement among the respondents about these items because the standard deviation is far from the mean. The next variable to be discussed is the identification and assessment process.

Table-5. Implementation of SIAS 2014 policy, identification and assessment process. $(\mathrm{N}=250)$

\begin{tabular}{|c|c|c|c|c|c|c|}
\hline \multicolumn{2}{|c|}{ Questionnaire Items } & Construct & Mean & Median & Standard & Cronbach's \\
\hline E1 & $\begin{array}{lcr}\text { I fill up the } & \text { Support } & \text { Needs } \\
\text { Assessment } & \text { (SNA) 1 } 1 & \text { from } \\
\text { secondary } & \text { sources } & \text { of } \\
\text { information. } & & \\
\end{array}$ & \multirow{5}{*}{$\begin{array}{l}\text { Internal and } \\
\text { external } \\
\text { support needs } \\
\text { assessment }\end{array}$} & \multirow{5}{*}{3.49} & \multirow{5}{*}{4.00} & \multirow{5}{*}{1.89} & \multirow{5}{*}{0.93} \\
\hline $\mathrm{E} 2$ & $\begin{array}{l}\text { I fill up the Support Needs } \\
\text { Assessment (SNA) 1 through } \\
\text { the completion and } \\
\text { implementation of the } \\
\text { Individual Support Plan (ISP). }\end{array}$ & & & & & \\
\hline E3 & $\begin{array}{l}\text { I include the learner during the } \\
\text { administration of SNA } 1 \text {. }\end{array}$ & & & & & \\
\hline E4 & $\begin{array}{l}\text { I include the parent or } \\
\text { caregiver of the learner during } \\
\text { the administration of SNA } 1 \text {. }\end{array}$ & & & & & \\
\hline F14 & $\begin{array}{l}\text { I implement recommendations } \\
\text { from professional practitioners } \\
\text { in the Form DBE } 126 \text { (Health } \\
\text { and Disability Assessment } \\
\text { Form) to support learners who } \\
\text { have been assessed by } \\
\text { professional experts. }\end{array}$ & & & & & \\
\hline
\end{tabular}

Statistical data in Table 5 show that the questionnaire items E1, E2, E3, E4, and F14 reached an excellent internal consistency of reliability $(\alpha=0.93)$. Data reveal that internal and external support needs assessment is not done in schools $(M=3.49 ; M D=4.00 ; S D=1.89)$. Internal support is done through the administration of SNA 1 whilst external support is done through the completion of Form DBE 126. Data are negatively skewed because the mean is below the median and there is no agreement among the respondents on these items because the standard deviation is far from the mean.

Data in Table 6 reveal that the Cronbach's alpha shows that the questionnaire items F2, F3, F5, F6, F8 and F10 have reached an excellent internal consistency of reliability $(\alpha=0.94)$. There is no internal support rendered to learners experiencing barriers to learning at schools $(M=3.62 ; M D=3.82 ; S D=1.92)$. Data are negatively skewed because the mean is below the median. The standard deviation is far from the mean which means that the respondents do not agree on the items. The external support questionnaire items F1, F4, F7, F9, D11, D13 and F13 reached a good internal consistency of reliability $(\alpha=0.88)$. Data also reveal that no external support is rendered to learners experiencing barriers $(M=3.57 ; M D=3.71 ; S D=1.92)$. Data is negatively skewed because the mean is 
below the median and there is no agreement among the respondents because the standard deviation is far from the mean.

Table-6. Implementation of SIAS 2014 policy, support.

$(\mathrm{N}=250)$

\begin{tabular}{|c|c|c|c|c|c|c|}
\hline \multicolumn{2}{|c|}{ Questionnaire Items } & Construct & Mean & Median & Standard & Cronbach's \\
\hline $\mathrm{F} 2$ & $\begin{array}{l}\text { I write the nature of support } \\
\text { that is suggested by the } \\
\text { learners who experience } \\
\text { learning barriers. }\end{array}$ & \multirow{6}{*}{$\begin{array}{l}\text { Internal } \\
\text { support }\end{array}$} & \multirow{6}{*}{3.62} & \multirow{6}{*}{3.82} & \multirow{6}{*}{1.92} & \multirow{6}{*}{0.94} \\
\hline F3 & $\begin{array}{l}\text { I write the nature of support } \\
\text { that is suggested by the } \\
\text { SBST. }\end{array}$ & & & & & \\
\hline F5 & $\begin{array}{l}\text { I write the nature of support } \\
\text { that I feel would be most } \\
\text { suitable to address the } \\
\text { learning barriers in the } \\
\text { learner. }\end{array}$ & & & & & \\
\hline F6 & $\begin{array}{l}\text { I include the learners' } \\
\text { opinions during the drawing } \\
\text { of the ISP. }\end{array}$ & & & & & \\
\hline F8 & $\begin{array}{l}\text { I include the input of the } \\
\text { curriculum manager (HOD) } \\
\text { during the drawing of the } \\
\text { ISP. }\end{array}$ & & & & & \\
\hline F10 & $\begin{array}{l}\text { I have access to the LURITS } \\
\text { system for planning lessons } \\
\text { that accommodate diversity of } \\
\text { learners. }\end{array}$ & & & & & \\
\hline $\mathrm{F} 1$ & $\begin{array}{l}\text { I write the nature of support } \\
\text { that is suggested by the } \\
\text { parents of learners who } \\
\text { experience learning barriers. }\end{array}$ & \multirow{7}{*}{$\begin{array}{c}\text { External } \\
\text { support }\end{array}$} & \multirow{7}{*}{3.57} & \multirow{7}{*}{3.71} & \multirow{7}{*}{1.92} & \multirow{7}{*}{0.88} \\
\hline $\mathrm{F} 4$ & $\begin{array}{l}\text { I write the nature of support } \\
\text { that is suggested by the } \\
\text { DBST. }\end{array}$ & & & & & \\
\hline F7 & $\begin{array}{l}\text { I include the opinions of the } \\
\text { parents or caregivers during } \\
\text { the drawing of the ISP. }\end{array}$ & & & & & \\
\hline F9 & $\begin{array}{l}\text { The DBST provides timeous } \\
\text { support to referrals from my } \\
\text { school. }\end{array}$ & & & & & \\
\hline D11 & $\begin{array}{l}\text { My HOD/supervisor } \\
\text { develops me on how I should } \\
\text { best support vulnerable } \\
\text { learners in my class. }\end{array}$ & & & & & \\
\hline D13 & $\begin{array}{l}\text { Community social workers } \\
\text { have developed me on how to } \\
\text { screen the social barriers in } \\
\text { the learners I teach. }\end{array}$ & & & & & \\
\hline F13 & $\begin{array}{l}\text { My school has a plan of action } \\
\text { about implementing } \\
\text { recommendations from } \\
\text { professional practitioners in } \\
\text { the Form DBE } 126 \text { (Health } \\
\text { Disability Assessment Form). }\end{array}$ & & & & & \\
\hline
\end{tabular}


Table-7. Implementation of SIAS 2014 policy, school type.

\begin{tabular}{|c|c|c|c|c|c|c|c|c|}
\hline Variables & $M$ & $S D$ & $t$ & $d f$ & $p$ & $M D$ & $C I$ & $d$ \\
\hline $\begin{array}{l}\text { Implementation of SIAS } 2014 \\
\text { policy }\end{array}$ & & & 3.93 & 248 & 0.00 & 31.70 & 15.81 to 47.60 & 0.06 \\
\hline Primary schools & 235.46 & 59.99 & & & & & & \\
\hline Secondary schools & 203.76 & 61.70 & & & & & & \\
\hline
\end{tabular}

Statistical data in Table 7 show that an independent-samples t-test was conducted to compare the application of SIAS 2014 policy between primary and secondary schools. There was a significant difference in the scores for primary $(M=235.46, S D=59.99)$ and secondary $(M=203.76, S D=61.70 ; t(248)=3.93, p=0.00$, two-tailed $)$. The magnitude of the differences in the means (mean difference $31.70,95 \%$ CI: 15.81 to 47.60 ) was moderate (eta squared $=.06)$. Since the interval does not include zero $(0)$ and probability value is .00, there is statistically significant difference between the means of primary and secondary schools in the application of SIAS 2014 policy.

\section{DISCUSSION OF FINDINGS}

The major signposts of the results about the screening process reveal that educators in primary and secondary schools do not screen the barriers experienced by the learners. Since the screening process is the initial step of the policy implementation, failure to execute directives about screening may lead to a collapse of all implementation efforts that may follow (Deiner, 2013; Mthethwa, 2014; Stofile, 2008). The schools also need to play their part in identifying and assessing the screened barriers. Implementation of the process of identification and assessment of barriers is ineffective in schools. The findings further reveal that some educators do not fill in the Support Needs Assessment (SNA) 1 form and for those who administer the SNA 1, they neither include learners nor their parents for whom the SNA 1 is administered (cf. Table 5). Moreover, some educators do not implement recommendations from professional practitioners about barriers which may have been identified and assessed to be affecting learners using Form DBE 126 which is a Health and Disability Assessment Form (cf. Table 5).

The poor implementation of the policy on identifying and assessing barriers may subject the policy to grievous implications. The policy may be facing rejection by its custodians, and this means it will be difficult for inclusive teaching and learning practices to be realised in South Africa. For any policy to become successfully implemented, the custodians of such a policy must apply it, even if application may not be perfect, but an application must be noted. Educators need to realise that for SIAS 2014 policy to ultimately become their useful tool not a burden, they must avail themselves to be recreated by its demands (Barringer et al., 2010; Erradu, 2012; Tomlinson, 2014). The findings suggest that there is no internal support rendered to learners experiencing barriers to learning at schools even though some studies (Acharya, 2009; Erradu, 2012; Ndou, 2015; Ntsanwisi, 2007) show that primary schools appeared to be better than secondary schools in terms of implementation. It is important to note that even though a better application was noted in primary schools, it may not mean that all phases of the primary schools are better at application of the policy.

It is also attested that primary school educators seem to be able to apply the policy mainly because they are with the learners the whole day, which gives them the opportunity to organise their teaching and learning time according to the support needs of learners (Acharya, 2009; Erradu, 2012; Ndou, 2015; Ntsanwisi, 2007). Insufficient time and lack of resources are believed to be some of the key obstacles in making any inclusive education policy a reality in many countries. Educators have been found to be rejecting the demands of inclusive education not because they hate learners who experience barriers to learning, but because they are expected to apply the policy within very narrow limits of time and skill. As a result, learners who need help end up neglected or even worse, their situation aggravated by the very people who are meant to support them. Educators at schools should be well 
inducted to adopt a positive mind-set to be passionate about inclusivity and the implementation of the SIAS 2014 policy (Dickins, 2014; Singh, 2010; Smith, Polloway, Patton, \& Dowdy, 2012). In this study, these discussions have been proven authentic given the fact that primary school educators appeared to be able to apply the SIAS policy largely because they had all the time to organise the curriculum content according to their needs while the secondary subject educators were compelled to share the time amongst all of them. Hence educators who were found to be applying the policy in more number were at primary schools.

\section{CONCLUSION}

This research has established that schools ineffectively implement the SIAS 2014 inclusive education policy in South Africa. The results revealed that there is no internal and external support of learners who experience barriers to learning using both the SNA1 and Form DBE 126 respectively. An effective application of the policy does not depend on the clarity of the policy directives but on the ability of educators to apply the policy. If the educators can screen the barriers in the learners competently and identify the type(s) of learning barriers experienced by the learners as well as assessing the needs of such learners, then such educators are not likely to have trouble in supporting such learners. Therefore, the researchers recommend that training and development of educators be intensified. The teacher training institutions should capacitate aspiring educators about inclusive education policies such as the SIAS 2014 policy rationale, principles, and how the policy is to be effectively implemented at schools. Induction and mentoring of beginning educators are essential. Educators at schools should be well inducted to adopt a positive mind-set to be passionate about inclusivity and the application of the SIAS 2014 policy.

Funding: This study received no specific financial support.

Competing Interests: The authors declare that they have no competing interests.

Acknowledgement: Both authors contributed equally to the conception and design of the study.

\section{REFERENCES}

Acharya, T. (2009). Strategies for overcoming barriers to educational development of scheduled caste students of Cuttack city. Journal of Social Sciences, 21(2), 85-89. Available at: https://doi.org/10.1080/09718923.2009.11892756.

Barringer, M., Pohlman, C., \& Robinson, M. (2010). Schools for all kinds of minds. San Francisco: Jossey-Bass.

Bouwer, C. (2016). Identification and assessment of barriers to learning. In E. Landsberg, D. Kruger \& E. Swart (Eds.). Addressing barriers to learning (pp. 73-93). Pretoria: Van Schaik.

Bronfenbrenner, U. (1979). The ecology of human development: Experiments by nature and design. England: Harvard University Press. Carkhuff, R. (2009). The art of helping. Amherst: Possibilities Publishing.

Cohen, L., Manion, L., \& Morrison, K. (2018). Research methods in education. New York: Routledge.

Deiner, P. L. (2013). Inclusive early childhood education development, resources and practice. Belmont: Wadsworth, Cengage Learning. Department of Basic Education. (2014). Policy on screening, identification, assessment and support. Pretoria: Government Printer.

Department of Education. (2008). National strategy on screening, identification, assessment and support. School Pack. Pretoria: Government Printer.

Dickins, M. (2014). A - Z of inclusion in early childhood. Berkshire: McGraw-Hill Education.

Erradu, J. (2012). Learner support to foundation phase learners who are intellectually impaired: A case study. Unpublished Master's Thesis. University of South Africa.

Fraenkel, J., Wallen, N., \& Hyun, H. (2015). How to design and evaluate research in education. New York: McGraw-Hill Education.

Gargiulo, R., \& Metcalf, D. (2013). Teaching in today's inclusive classrooms. Belmont: Wadsworth, Cengage Learning.

Glazzard, J., Stokoe, J., Hughes, A., Netherwood, A., \& Nerve, L. (2015). Teaching \& supporting children with special educational needs $\Xi^{2}$ disabilities in primary schools. Los Angeles: Sage.

Grbich, C. (2013). Qualitative data analysis: An introduction. London: Sage. 
Jansen, D. (2016). Introduction to the language of research. In K. Maree (Ed.). First steps in research (pp. 16-24). Pretoria: Van Schaik.

Johnson, R., \& Christensen, L. (2017). Educational research: Quantitative, qualitative and mixed approaches. Los Angeles: Sage.

Landsberg, E., \& Matthews, L. (2016). Learning support. In E. Landsberg, D. Kruger \& E. Swart E. (Eds.). Addressing barriers to learning (pp. 95-116). Pretoria: Van Schaik.

Leedy, P., \& Ormord, J. (2015). Practical research. Boston: Pearson Education.

Moyo, N., Modiba, M., \& Simwa, K. (2015). Critical research: Understanding material constraints and engaging in transformative action research. In C. Okeke \& M. Van Wyk (Eds.), Educational research: An African approach (pp. 5876). Cape Town: Oxford University Press.

Mthethwa, B. S. V. (2014). Public management and governance. Unpublished PhD Thesis. North-West University, Potchefstroom Campus.

Ndou, N. (2015). Managing the implementation of education policies for quality education in public schools of Limpopo Province. Unpublished Doctoral Thesis. University of South Africa.

Nel, N., Nel, M., \& Hugo, A. (2012). Inclusive education: The necessity of providing support to all learners. In N. Nel, M. Nel \& A. Hugo (Eds.), Learner support in a diverse classroom: A guide for foundation, intermediate and senior phase teachers of language and mathematics (pp. 3-24). Pretoria: Van Schaik.

Ntsanwisi, L. N. (2007). The identification of barriers to learning by Grade 3 educators in the Ritavi District of Limpopo Province. Unpublished Master's Thesis. University of Limpopo.

Singh, M. (2010). Education of children with special needs. New Delhi: Kanishka.

Smith, T. E. C., Polloway, E. A., Patton, J. R., \& Dowdy, C. A. (2012). Teaching students with special needs in inclusive settings. Boston: Pearson Education.

Stofile, S., Y. (2008). Factors affecting the implementation of inclusive education policy: A case study in one province in South Africa. Unpublished Doctoral Thesis. University of Western Cape.

Swart, E., \& Pettipher, R. (2016). A framework for understanding inclusion. In E. Landsberg, D. Kruger \& E Swart (Eds.), Addressing barriers to learning (pp. 3-27). Pretoria: Van Schaik.

Taylor, R. L., Smiley, L. R., \& Richards, S. B. (2015). Exceptional students: Preparing teachers for the 21st century. New York: McGraw-Hill Education.

Tomlinson, A. C. (2014). The differentiated classroom: Responding to the needs of all learners. Alexandria: ASCD.

Views and opinions expressed in this article are the views and opinions of the author(s), International Journal of Education and Practice shall not be responsible or answerable for any loss, damage or liability etc. caused in relation to/arising out of the use of the content. 